\title{
Students Attitude and Perceptions towards Academic Dishonesty
}

\author{
Young D. Nwoye \\ Department of Accounting and Finance \\ Virginia State University \\ Uchenna N. Akpom \\ Department of Accounting, Finance and Economics \\ The University of West Alabama \\ Jae-Kwang Hwang \\ Department of Accounting and Finance \\ Virginia State University
}

\begin{abstract}
Academic dishonesty is one of the most evasive student behaviors facing faculty and administrators in schools. Dishonest behavior in schools is an ethical issue of concern to the academic and business communities. Various methods have been used to try to understand and combat academic dishonesty. In some cases, severe punishments have been used with mixed results. An understanding of students' attitude and perceptions about academic dishonesty is essential in determining the proper solution to academic dishonesty. This study looks at student perceptions of academic dishonesty at numerous colleges and universities in South East and Northern part of Nigeria. It also evaluates how the perceptions of male students may vary from those of female students. In addition to these, it seeks to identify some factors that predict students' attitudes toward academic dishonesty.
\end{abstract}

Keywords: Academic Dishonesty, Cheating, Situational, Perception, Attributional, Plagiarism, Students, Educational system.

\section{Introduction}

Academic dishonesty has been defined as a wider concept encompassing a set of deliberate but unacceptable behaviors that are against academic rules and regulations of a university or a particular course policy stated in the course outline (Tefera and Kinde, 2009). Following this definition, cheating, seeking outside assistance and plagiarizing have become a worldwide issue in academic discourse. Academic dishonesty comes in various forms. The most common form of academic dishonesty includes using crib notes on a test, copying from another student on a test with or without his or her knowledge, using unfair methods to find out in advance what will be on a test, helping someone else cheat on a test, and cheating on a test in some other way or form (Cazan \& Iacob, 2017). Students perceive these unethical activities as an ordinary common school acts. According to Balbuena and Lamela (2015), students allay their actions on teacher's and student's incompetence, unfavorable environment, higher social pressure or expectation and lenient imposition of administrative or school policy. Furthermore, the triviality of this unethical behavior has permeated to its continuous existence and practice. As a result, some would rather cheat to live up to expectation than abide by ethical standard to lag at school. These scenarios create an ethical dilemma which confuses students when making decisions. In addition to the above are the inconsistencies in the societal valued system in which schools impose policy, from the teacher's response to ethical activities and the opportunities given by the school environment.

The need for research in this field cannot be overstated. In their study, Mohr, Ingram, Fell and Mabey (2011), speculated that unethical behavior such as cheating and plagiarism will more likely result to unethical behavior in the place of work. Resurreccion (2012), argued that if a higher institution should be identified for poor academic integrity, the community and other stakeholders will tend to lose trust on the degrees that are conferred on the graduates and on the capability and moral character of the graduates themselves. This is one of the most justifiable reasons why the study of academic dishonesty has risen to the forefront in less developed countries. As these economies struggle to improve their competitive positions in the world economies, it is imperative that they provide an environment that facilitates economic growth. It is therefore pertinent at this juncture to elicit the various forms of academic dishonesty in order to gain insight into student's attitude and perception towards such unethical behavior. 
In the case of Nigeria, academic dishonesty is not a recent phenomenon. The incidents of academic dishonesty have been documented by earlier Nigerian researchers (Adebayo, 2011; Orim, 2016). This issue has presented major problem to the Nigerian education system. In a recent study conducted in two Nigerian institutions, Ubaka, Gbenga, Sunday and Ndidiamaka (2013) showed that $54.2 \%$ of undergraduate pharmacy students had been involve in academic dishonesty in the preparation of their academic exercises. Many studies have looked at different aspects of academic dishonesty in Nigeria, though most studies concentrate on exam malpractice.

Numerous suggestions have been presented to explain the causes of this and to provide solutions to academic dishonesty (Olasehinde, 2007, and Crown \& Spiller, 1998; Marzean, 2001). To adequately deal with the problem of academic dishonesty, it is important to understand how students think about it, and what affects their decisions to engage in educational dishonest and unethical behavior.

Previous efforts to reduce academic dishonesty among students in Nigeria have not been successful. Many of the measures merely seek to reduce cases of academic dishonesty rather than target why students engage in academic dishonesty in the first place. To that extent, the measures have merely been dealing with the symptoms without addressing the root of academic dishonesty. The rest of this study is divided into five subsequent sections. Section two provides a brief historical background of Nigerian educational system. Section three reviews literatures on academic dishonesty and other examination malpractices. Section four describes the data, methodology and model used. Section five highlights the results, and section six presents the conclusions.

\section{Study Area Background}

Nigerian educational system encourages students to compete from their first experience with formal education in Nigeria. Once they are admitted into elementary schools, they realize that the primary way to continue progressing with their education is to outperform other students. After elementary school, most states require that students take a common entrance exam. Students' scores on these exams determine which high schools they are posted to. The better the student's score, the more likely it is that he or she would be posted to the school of his or her first choice. Students who do not meet the minimum score requirement are left to attend some lower quality parochial schools.

After graduation from high school, the students are required to take a standardized national exam that determines whether they would be admitted to a university. This high-stakes testing approach means that students would do almost anything they could to succeed academically. The continuing trend of cheating on exams in Nigeria can be attributed to these requirements. To make things worse, the level of competition for admission to universities in Nigeria is high. A recent study by the federal government of Nigeria indicates that less than fifty percent of qualified Nigerians can gain admission to Nigerian universities because of limited spaces in the universities. Academic dishonesty in Nigerian higher institutions is not a recent phenomenon. Studies indicate that the rate of academic dishonesty in higher institutions in the country has continued to increase at an alarming rate.

This study was sponsored by the US Department of States as part of a Fulbright grant. The study site was hosted by the University of Nigeria, Enugu, Nigeria and Nasarawa State University, Keffi, Nasarawa. The University of Nigeria, commonly referred to as UNN, is a federal university located in Nsukka, Enugu State. UNN is located in Southeast of Nigeria with an estimated student population of 40,000 in 2015-2016. The University of Nigeria has three campuses Nsukka, Enugu and Ituku-Ozalla - located in Enugu State. These surveys were carried out at the Enugu campus (UNEC), which housed the Faculty of Medicine, Law, Business (Banking and Finance, Marketing, Management, Accounting), Architecture and many others.

Unlike the University of Nigeria, Nsukka, Nasarawa State University, Keffi is a young university situated in the middle belt region of Nigeria. This region is Hausa speaking and predominantly Muslims. Nasarawa State University was established under the Nasarawa State Law No. 2 of 2001 as passed by the State House of Assembly. The University comprises faculties of Business Administration, Agriculture, Arts, Education, Law, Natural and Applied Science, and Social Science. The estimated student population in 2015-2016 was 26, 000.

\section{Literature Review}

Academic dishonesty is not a recent phenomenon in Nigeria. According to Alutu and Aluede (2005), the first publicly reported incident of academic dishonesty in Nigeria occurred in 1914, when there was leakage in question papers in the Senior Cambridge Local Examination. This trend continues today as the examinations bodies in the country continue to cancel national examination results due to examination malpractices (Alutu and Aluede, 2006).The continued persistence of academic dishonesty is a symptom or signs of the collapse of the country's educational system. 
Academic dishonesty in the country is not limited to examination malpractice. Such practices include plagiarism, paying other students to write a student's projects, paying instructors for high grades for exams or projects that in many cases the student did not participate in. Interest in the causes of academic dishonesty continues to persist.

A wide range of factors have been identified as determinants of academic dishonesty. In his study, Adeyemi (2010) indicates that indiscipline among students is a critical determinant of examination malpractices in Nigerian schools. Whitley (1998) echoing this suggest that academic dishonesty is a moral issue. According to Yang, Huang and Chen (2013), students perceive that their peers are more likely to engage in academic dishonesty and are motivated to do so. They stated that students are willing to report classmates than friends.

Furthermore, competition, pressures for good grades, excessively demanding educational systems, peer pressures to support a friend, and a diminishing sense of academic integrity and ethical values among students have also been identified as possible causes of academic dishonesty (Rabi, Patton, Fjortoft, \& Zgarrick, 2006). Olatunbosun (2009) identified societal apathy as the major factor that sustains examination malpractice in the Nigeria. Regardless of the causes of academic dishonesty, it is obvious that it is a behavioral problem, and requires behavioral change. Huang, Yang and Chen (2015) in their survey of 431 Taiwanese university students reveals that approach oriented students tend to use self-promotion and interest as reasons for academic dishonesty rather than citing a sense of inadequacy.

These findings appear reasonable because, in comparison to avoidance-oriented students, approach-oriented students usually exhibit more learning ambition and are likely to devote greater effort to their schoolwork. Thus, feelings of incompetency would not cause them to engage in academic dishonesty. Instead, their decision to engage in academic dishonesty is likely to be based on their rationalization that the personal benefits derived from doing so, which are based on a desire for success or promotion or on the fear of failure, are greater than the ethical constraints that are violated. They also found that students had a low willingness to report peers' academic dishonesty, consistent with the findings of other researchers.

Rabi, Patton, Fjortoft, and Zgarrick (2006)proposed that the desire to maintain a friendship and to avoid being an outcast as reasons for this low willingness to report others' academic dishonesty. Furthermore, they also found that among students with a high willingness to report friends' and classmates' academic dishonesty, those with a higher willingness to report the former, in comparison to the latter, were more likely to consider self-interest and promotion as their motivations for academic dishonesty and less likely to be motivated by inadequacy. It was inferred that these students were driven by competition. Because the educational system in Taiwan is competition oriented, students compete with others (including friends and peers) for future scholarships, education, and employment opportunities and they tended to boast about and highlight their achievements to receive attention.

Therefore, some students might be more willing than others to report their peers' AD and more inclined to engage in cheating on an examination or deceptive infringement forms of academic dishonesty, and they might justify their academic dishonesty with self-interest/promotion. In a survey of 79 criminology students at an Australian university, Eriksson and McGee (2015) found that male gender is an individual characteristic predictive of higher involvement in academic dishonesty. Furthermore, perceptions of peer engagement in academic dishonesty was not found to be predictive of student behavior in their study, despite the research literature frequently report peer behavior as one of the main predictors of academic dishonesty. In addition, language background was not found to be predictive of engagement in academic dishonesty in the study.

Jones (2011) conducted a study about academic dishonesty with a group of 48 students enrolled in an online business communication course during fall semester, 2010. She found that many students believed that it was okay to cheat. Of the students surveyed, 92\% indicated that they had or they knew someone who had cheated. Students rated Internet plagiarism lower than cheating, but identified Internet plagiarism as a form of cheating commonly used. She further found out that the reasons students engaged in academic dishonesty - cheating and Internet plagiarism varied, but as commonly understood, the overriding reason was performance. The top three responses from a list of nine items were grades (92\%), procrastination (83\%), and too busy, not enough time to complete assignment or study for test (75\%). Her study revealed that several students had difficulty identifying what was and what was not plagiarism/cheating. Similarly, according to the students surveyed, the primary ways information about academic integrity was being disseminated at the university were (a) informally from professors' lectures or talks (75\%), (b) discussions of current events involving ethical issues (67\%), and (c) the university.

Rinn, et. al. (2014) in their study assessed a measure of academic dishonesty and examined high ability college students' loci of control and its relationship to behaviors of academic dishonesty, as moderated by academic self-concept. The researchers examine a sample of 357 high ability students from two universities in the southwestern United States, in two subsamples, honors students and non-honors students. They found out that membership in an honors program has potentially greater consequences for academic dishonesty (e.g., being kicked out of the program, losing scholarships). 
Locus of control was not statistically significantly correlated with academic dishonesty in the whole-group, nor in the honors group. Meanwhile, correlation results in the non-honors group showed a small yet significant correlation between locus of control and the external motivation for academic dishonesty factor. Furthermore, while academic selfconcept remained an important variable in the prediction of academic dishonesty, it did not moderate the relationship between locus of control and academic dishonesty in the study. They concluded that other achievement-related beliefs need to be explored as precursors to academic self-concept, and as predictors of academic dishonesty, among high ability college students.

Sulphey and Jnaneswar (2013) conducted a survey of 154 respondents in order to ascertain the relationship between academic dishonesty, anomia and unethical behavior among business graduates. From the analysis it was found that significant correlation was found between Academic dishonesty and unethical behavior. Significant correlation was observed only between the variables academic dishonesty and attitude towards managers' unethical behavior in the business context. Correlation analysis revealed significant positive relationship with anomia and age group. Significant negative correlation was observed between attitude towards managers' unethical behavior, and age. No significant difference was found between the first and second year students for all the three variables.

\section{Data and Methodology}

This study uses a student self-report survey questionnaire designed after the one used by McCabe (2009). This questionnaire contains 18 academic dishonesty situation questions, 7 student perception questions, and 5 demographic questions.

Response options to the situational questions utilized a five-scale Likert-type format questions ranging from 0 for "definitely not academic dishonesty," to 5 for "definitely academic dishonesty.' Responses to the perception questions ranged from 0 for" strongly disagree," to 4 "strongly agree."The demographic questions included gender, academic classification, age, income, and major field of study.

The survey for this study was administered to students in the Faculties (Colleges or Schools) of business, engineering, health, law, arts and sciences, and education in two large public universities in Nigeria during the 2015/2016 academic year. The questionnaire was administered to first through fifth year students at the University of Nigeria, Nsukka and Nasarawa State University, in Keffi, Nigeria. Due to the difficulty of obtaining a randomly selected population, a convenience sample was used.The survey was carried out during the regular class period. Instructors were recruited to administer the questionnaires in their classes. All questionnaires were administered the same semester to different classes from different degree programs. A total of one thousand five hundred questionnaires were administered. Questionnaires containing missing answers were not included in the study. One thousand three hundred and ten contained complete information and were included in the study. The interest in this study is on students' understanding and perceptions towards academic dishonesty.

Descriptive statistics for the data are presented in Table 1.The sample distribution shows that 61.4 percent of the students were from the University of Nigeria while 38.6 percent were from Nasarawa State University. Out of the 1,310 students sampled, $62 \%$ were male students while $38 \%$ were female students. Twenty three percent of the students were first year students, $42 \%$ were second year students, $14 \%$ were third year students, $2 \%$ were fourth year students while 19 percent were fifth year students. Over 56 percent were twenty-one years old or less. About 30 percent of the students were in the 22-24 years age range. Only about 14 percent of the sample were older than twenty-five years old. This indicates a younger population consistent with the fact that the main source of admissions to universities in Nigeria, especially public universities are recently graduating secondary school students. 
Table 1: Descriptive Statistics

\begin{tabular}{|c|c|}
\hline Variable & Mean \\
\hline \multicolumn{2}{|l|}{ University } \\
\hline University of Nigeria, Enugu Campus & 3.921 \\
\hline Nasarawa State University & 2.014 \\
\hline \multicolumn{2}{|l|}{ Student's gender } \\
\hline Male student & 0.622 \\
\hline Female student & 0.378 \\
\hline \multicolumn{2}{|l|}{ Academic classification } \\
\hline First year & 0.231 \\
\hline Second year & 0.421 \\
\hline Third year & 0.137 \\
\hline Fourth year & 0.016 \\
\hline Fifth year & 0.195 \\
\hline \multicolumn{2}{|l|}{ Age in years } \\
\hline Less than 21 & 0.564 \\
\hline AGE2 & 0.295 \\
\hline AGE3 & 0.096 \\
\hline AGE4 & 0.032 \\
\hline More than 30 & 0.014 \\
\hline \multicolumn{2}{|l|}{ Household monthly income } \\
\hline$\leq \mathrm{N} 75,000$ & 0.472 \\
\hline N75,001-N100,000 & 0.123 \\
\hline N100,001-N150,000 & 0.126 \\
\hline N150,001-N175,000 & 0.074 \\
\hline$>\mathrm{N} 175,000$ & 0.205 \\
\hline \multicolumn{2}{|l|}{ Faculty, college or school } \\
\hline Faculty of Business & 0.269 \\
\hline Faculty of Engineering & 0.293 \\
\hline School of Nursing & 0.092 \\
\hline College of Law & 0.137 \\
\hline Faculty of Arts and Sciences & 0.194 \\
\hline College of Education & 0.014 \\
\hline
\end{tabular}

The income distribution of the sample shows that $47.2 \%$ of the respondents had household income of N75,000 per month or less, representing the largest group. Another $20.5 \%$ had income level above N175,000 per month. This is consistent with the fact that tuition in public universities are generally lower than tuition in private universities. The two universities samples are public universities. The field of concentration data shows that about 27 percent of the students were in the faculty of business while 29 percent were in the faculty of engineering. Arts and sciences faculty, law faculty, nursing school, and faculty of education represented $19.4 \%, 13.7 \%, 9.2 \%$, and $1.4 \%$ of the sample respectively.

\section{Results}

The results for this study are presented in two formats. First the means of the responses to both the situation questions and students' perception questions were presented. Secondly, regression analysis of the responses was presented showing the effects of perceptions by students on their knowledge about academic dishonesty. Table 2 present students' responses to academic dishonesty situation questions. Students' awareness and recognition of these questions are at the core and purpose of this study. The results show that the students were 
mostly able to recognize the situations as being academically dishonest situations however there were still circumstances where the students did not perceive the situation to represent academic dishonesty. Out of the 18 academic dishonesty situation questions, only one had a mean less than 3. Since a 5-scale Likert type format was used, we assumed that mean score less than 2.5 indicated lack of recognition of academic dishonesty situation, 2.5-3.5 indicated uncertainty while mean score above 3.5 indicated recognition of academic dishonesty situation. Based on this, the study showed a general understanding of what academic dishonesty was. Out of the 18 situations, the students had definite knowledge that thirteen of the situations represented academic dishonesty. Five of the means fell within the uncertainty range indicating that the students did not recognize these as definitely academic dishonesty situations.

Table 2: Mean scores on the academic dishonesty situation questions

\begin{tabular}{|c|c|c|c|c|c|}
\hline Variable & & Mean & StDev & Min & Max \\
\hline 1 & $\begin{array}{l}\text { Edgar and Cindy are working together on an assignment meant to be } \\
\text { completed individually. }\end{array}$ & 3.164 & 1.504 & 1 & \\
\hline 2 & $\begin{array}{l}\text { Emeka was given a class assignment to complete for a grade. He took the } \\
\text { assignment work to a friend for guidance. }\end{array}$ & 4.435 & 0.916 & 2 & 5 \\
\hline 3 & $\begin{array}{l}\text { This semester, Adamu's class was given an assignment. Luckily, he did } \\
\text { the same assignment last semester so he submitted the assignment from a } \\
\text { previous subject in a new subject. }\end{array}$ & 3.452 & 1.453 & 1 & 5 \\
\hline 4 & $\begin{array}{l}\text { Biola had a paper to write. She found out that her friend happens to have } \\
\text { a paper similar to the one she submitted last semester so she exchanged } \\
\text { papers with her friend for a grade. }\end{array}$ & 4.073 & 1.288 & 1 & 5 \\
\hline 5 & $\begin{array}{l}\text { To save time Kofi copied John's assignment with John's permission and } \\
\text { submitted it for a grade in his current course. }\end{array}$ & 4.012 & 1.314 & 1 & 5 \\
\hline 6 & $\begin{array}{l}\text { Mary was busy preparing for another exam so she pays Ngozi to write } \\
\text { the assignment for her. }\end{array}$ & 4.213 & 1.249 & 1 & 5 \\
\hline 7 & $\begin{array}{l}\text { Baba found another student's assignment at the cafeteria and decided to } \\
\text { copy and submit it for a grade without his writer's knowledge. }\end{array}$ & 4.329 & 1.194 & 1 & 5 \\
\hline 8 & $\begin{array}{l}\text { Emeka's professor made an error on Emeka's grade. He did not inform } \\
\text { the teacher of the error because she gave him too high a mark. }\end{array}$ & 3.419 & 1.385 & 1 & 5 \\
\hline 9 & $\begin{array}{l}\text { In conducting research for a term paper Akpan found a good paper on } \\
\text { the internet and obtained a lot of information from it. His paper did not } \\
\text { contain any references. }\end{array}$ & 3.496 & 1.439 & 1 & 5 \\
\hline 10 & $\begin{array}{l}\text { Emma copied most of an assignment from his friend's assignment, but } \\
\text { put a fair bit of work on the paper. }\end{array}$ & 3.238 & 1.305 & 1 & 5 \\
\hline 11 & $\begin{array}{l}\text { This is Caleb's last attempt at passing this subject. Luckily, he found } \\
\text { someone to take it for him for a fair amount of money. }\end{array}$ & 4.341 & 1.178 & 1 & 5 \\
\hline 12 & Ada used a hidden sheet of paper with answers during an exam. & 4.564 & 1.057 & 1 & 5 \\
\hline 13 & $\begin{array}{l}\text { Ayodele was not prepared for the midterm exam so he obtained a } \\
\text { medical certificate from his friend, a doctor, to get an extension for the } \\
\text { exam. }\end{array}$ & 3.876 & 1.381 & 1 & 5 \\
\hline 14 & $\begin{array}{l}\text { Amaka worked hard on her final paper. She was able to copy materials } \\
\text { from a text book to complete the paper. }\end{array}$ & 2.739 & 1.512 & 1 & 5 \\
\hline 15 & $\begin{array}{l}\text { Dr. Kudi gave his class two assignments to complete. Ibrahim exchanged } \\
\text { assignments with a friend, so that each does one assignment, instead of } \\
\text { two. }\end{array}$ & 3.512 & 1.339 & 1 & 5 \\
\hline 16 & $\begin{array}{l}\text { Jaja and Wale are close friends. Jaja noticed that Wale was looking at his } \\
\text { exam when he was stuck on a problem during final exam, Jaja left his } \\
\text { exam open to help his friend pass. }\end{array}$ & 3.688 & 1.319 & 1 & 5 \\
\hline 17 & $\begin{array}{l}\text { Nwoke was not quite sure about his final exam so he copied some } \\
\text { answers on a sheet of paper and took it into the exam. }\end{array}$ & 4.521 & 1.061 & 1 & 5 \\
\hline 18 & $\begin{array}{l}\text { John knew that most students did it so he paid money to obtain a good } \\
\text { grade in a course. }\end{array}$ & 4.530 & 1.054 & 1 & 5 \\
\hline
\end{tabular}

For the questions related to working together on assignment meant to be complete individually, using the same assignments from a previous class for the current class, bringing a favorable grading error to the attention of the professor, copying assignment from a friend's work while putting a fair amount of work, and copying materials from a textbook to complete a final paper, the mean scores of 2.74 to 3.45 did not indicate knowledge of these as definite academic dishonesty situations. The students were most aware that bringing cheat sheets into an exam and paying money to obtain a good grade in a course represented academic dishonesty. 
Students attitudes and perceptions about academic dishonesty are presented in Table 3 . The mean response to the question of people losing respect for them if they found out that the student had help was 3.07.About $45.76 \%$ of the respondents agreed with the statement however $38.19 \%$ disagreed. The percentage that disagreed with the statement was higher than anticipated. When presented with the statement "I do not care whether I am caught or not as long as I passed the exam," the mean response for was 2.01. For this question, $73.52 \%$ disagreed which was consistent with our expectation. The implication is that students consider other students' views about them when they make their decision to be involved in academic dishonesty or not. In another statement, students were told "passing is the most important thing to me," $57.55 \%$ agreed with it. This was surprisingly high especially because many cared whether they are caught or not. In addition, $75.86 \%$ felt that there was a good chance that they could be caught if they cheated on exam.

Table 3: Students' responses to personal perceptions of academic dishonesty

\begin{tabular}{lll}
\hline Variable & Perceptions toward academic dishonesty & Mean \\
\hline RESPECT & People would lose respect for me is they found out that I had help. & 3.074 \\
CAUGHT & There is a good chance that I would get caught if I looked at another & 3.921 \\
& student's exam. & 2.014 \\
CARELESS & I would not care whether I am caught or not as long as I pass the exam. & 3.534 \\
PASSING & Passing is the most important thing to me. & 3.928 \\
PRESSURE & There is too much pressure on students to pass a course. & 3.737 \\
OTHERS & Other students will cheat on exams if they could. & 4.046 \\
PREPARED & I consider myself well prepared for exams. & \\
\hline
\end{tabular}

When presented with the statement that "there was too much pressure on students to pass a course," $73.21 \%$ agreed with it. About sixty-six percent of the respondents agreed with the statement "other students will cheat on exams if they could." This attitude could provide an incentive for students to cheat. On the statement "I consider myself well prepared for exams," 74.81 of the respondents agreed with it. Overall, the responses were as expected except for two of the statements.

Determinants of knowledge about academic dishonesty

To determine the factors that influence knowledge about academic dishonesty, a multiple regression analysis was utilized. The model specified assumes that score on the academic dishonesty situation statements are a function of student demographic characteristics and student attitudes toward academic dishonesty. This model is specified as:

$$
\mathrm{AD}=f(\text { demographics, student attitudes) }
$$

hence

$$
\underset{\text { Where } \mathrm{i}}{A D}=1,2, \beta i \sum_{i=1}^{n} D i j+\ldots i \sum_{i=1}^{n} S i k+e i
$$
demographic variables, and $\mathrm{k}=1,2,3, \ldots \mathrm{K}$ denotes number of attitude variables. $\mathrm{N}=1,310, \mathrm{M}=18$, and $\mathrm{K}=$ 7 in this study. $\alpha, \beta$, and $\delta$ are estimates, Ds are demographic characteristics, Ss are student attitudes and $\mathrm{e}_{\mathrm{i}}$ is the error term assumed to be identical, independent and with mean zero distribution.

The above function can be specified for this study as:

$\mathrm{ADSC}=\delta_{0}+\beta_{1} \mathrm{FEM}+\beta_{2} \mathrm{YR} 2+\beta_{3} \mathrm{YR} 3+\beta_{4} \mathrm{YR} 4+\beta_{5} \mathrm{YR} 5+\beta_{6}$ AGE $2+\beta_{7}$ AGE3 $+\beta_{8}$ AGE4 $+\beta_{9}$ AGE $5+$ $\beta_{10} \mathrm{INC} 2+\beta_{11} \mathrm{INC} 3+\beta_{12} \mathrm{INC} 4+\beta_{13} \mathrm{INC} 5+\beta_{14} \mathrm{ENG}+\beta_{15} \mathrm{NUR}+\beta_{16} \mathrm{LAW}+\beta_{17} \mathrm{~A} / \mathrm{S}+\beta_{18} \mathrm{EDUC}+\delta_{1} \mathrm{RESP}+$ $\delta_{2} \mathrm{CGHT}+\delta_{3}$ CLESS $+\delta_{4} \mathrm{PASS}+\delta_{5} \mathrm{PRESS}+\delta_{6} \mathrm{OTHER}+\delta_{7} \mathrm{PREP}+\mathrm{e}_{\mathrm{i}}$

Table 4 presents definition of variables used for the regression analysis. Table 5 contains the Pearson's correlation coefficients for the independent variables. A review of the correlation coefficients indicates that most of the independent variables are not highly correlated. All the correlations between the variables are less than 0.4 except ENG and YR2 (0.66), and LAW and YR5 (0.78). This suggests that multicollinearity was not a problem in this regression. This lack of multicollinearity problem is also supported by the estimated Variance Inflation Factors (VIF) presented in Table 6. VIF measures how much the variance of the estimated regression coefficient is "inflated" by the existence of correlation among the independent variables in the model (Penn State University, 2018). If there is no correlation among the independent variables, the VIF will equal 1. 
The general rule of thumb is that VIFs exceeding 4 warrant further investigation, while VIFs exceeding 10 are signs of serious multicollinearity (Penn State University, 2018). An examination of Table 6 indicates that the VIFs for the variables are all less than 2 except for five which are less than 4 and another 1 which is less than 6.

Table 4: Definition of variables

\begin{tabular}{|c|c|}
\hline Variable & Definition \\
\hline MALE & 1 if male, otherwise, 0 . \\
\hline FEM & 1 if female, otherwise, 0 . \\
\hline YR1 & Academic classification, 1 if first year student, otherwise, 0 . \\
\hline YR2 & Academic classification, 1 if second year, otherwise, 0 . \\
\hline YR3 & Academic classification, 1 if third year, otherwise, 0 . \\
\hline YR4 & Academic classification, 1 if fourth year, otherwise, 0 . \\
\hline YR5 & Academic classification, 1 if fifth year, otherwise, 0 . \\
\hline AGE1 & I if age is less than 21 years, otherwise 0 . \\
\hline AGE2 & I if age is 22 to 24 years, otherwise, 0. \\
\hline AGE3 & I if age is 25 to 27 years, otherwise, 0. \\
\hline AGE4 & I if age is 28 to 30 years, otherwise, 0. \\
\hline AGE5 & I if age is over 30 years, otherwise, 0 . \\
\hline $\mathrm{INC} 1$ & 1 if income is less than or equal to $\mathrm{N} 75,000$ per month. \\
\hline $\mathrm{INC} 2$ & 1 if income is $\mathrm{N} 75,001$ to $\mathrm{N} 100,000$ per month. \\
\hline INC3 & 1 if income is $\mathrm{N} 101,000$ to $\mathrm{N} 150,000$ per month. \\
\hline INC4 & 1 if income is $\mathrm{N} 151,000$ to $\mathrm{N} 175,000$ per month. \\
\hline INC5 & 1 if income is more than $\mathrm{N} 175,000$ per month. \\
\hline BUS & 1 if a business major, otherwise, 0 . \\
\hline ENG & 1 if an engineering major, otherwise, 0 . \\
\hline NUR & 1 if a nursing major, otherwise, 0 . \\
\hline LAW & 1 if a law major, otherwise, 0 . \\
\hline $\mathrm{A} / \mathrm{S}$ & 1 if arts and science major, otherwise, 0 . \\
\hline EDU & 1 if an education major, otherwise, 0 . \\
\hline RESP & People would lose respect for me is they found out that I had help. \\
\hline CGHT & There is a good chance that I would get caught if I looked at another student's exam. \\
\hline CLESS & I would not care whether I am caught or nor as long as I pass the exam. \\
\hline PASS & Passing is the most important thing to me. \\
\hline PRESS & There is too much pressure on students to pass a course. \\
\hline OTHER & Other students will cheat on exams if they could. \\
\hline PREP & I consider myself well prepared for exams. \\
\hline
\end{tabular}

Incomes based on 2015 incomes. 
Table 5: Correlation coefficients

\begin{tabular}{|c|c|c|c|c|c|c|c|c|c|c|c|c|c|}
\hline & RES & $\mathrm{CTH}$ & CLESS & PAS & PRE & OTH & PREP & $\mathrm{F}$ & YR2 & YR3 & YR4 & YR5 & $22-24$ \\
\hline RESPECT & 1.00 & & & & & & & & & & & & \\
\hline \multirow[t]{2}{*}{ CAUGHT } & 0.16 & 1.00 & & & & & & & & & & & \\
\hline & 0.00 & & & & & & & & & & & & \\
\hline \multirow[t]{2}{*}{ CARELESS } & -0.06 & -0.14 & 1.00 & & & & & & & & & & \\
\hline & 0.03 & 0.00 & & & & & & & & & & & \\
\hline \multirow[t]{2}{*}{ PASSING } & -0.09 & 0.02 & 0.17 & 1.00 & & & & & & & & & \\
\hline & 0.00 & 0.43 & 0.00 & & & & & & & & & & \\
\hline \multirow[t]{2}{*}{ PRESSURE } & 0.07 & 0.14 & -0.06 & 0.16 & 1.00 & & & & & & & & \\
\hline & 0.01 & 0.00 & 0.04 & 0.00 & & & & & & & & & \\
\hline \multirow[t]{2}{*}{ OTHERS } & 0.05 & 0.06 & -0.01 & 0.12 & 0.26 & 1.00 & & & & & & & \\
\hline & 0.07 & 0.03 & 0.73 & 0.00 & 0.00 & & & & & & & & \\
\hline \multirow[t]{2}{*}{ PREPARED } & 0.01 & 0.09 & -0.01 & 0.11 & 0.05 & 0.07 & 1.00 & & & & & & \\
\hline & 0.86 & 0.00 & 0.77 & 0.00 & 0.06 & 0.01 & & & & & & & \\
\hline \multirow[t]{2}{*}{$\mathrm{F}$} & 0.04 & 0.11 & -0.08 & 0.04 & 0.06 & 0.08 & 0.01 & 1.00 & & & & & \\
\hline & 0.13 & 0.00 & 0.00 & 0.12 & 0.03 & 0.01 & 0.84 & & & & & & \\
\hline \multirow[t]{2}{*}{ YR2 } & 0.01 & 0.05 & -0.02 & -0.04 & 0.07 & 0.02 & 0.02 & -0.22 & 1.00 & & & & \\
\hline & 0.84 & 0.10 & 0.44 & 0.13 & 0.01 & 0.59 & 0.38 & 0.00 & & & & & \\
\hline \multirow[t]{2}{*}{ YR3 } & 0.05 & 0.05 & 0.00 & -0.03 & 0.04 & 0.06 & -0.04 & 0.21 & -0.34 & 1.00 & & & \\
\hline & 0.06 & 0.11 & 0.97 & 0.35 & 0.16 & 0.05 & 0.12 & 0.00 & 0.00 & & & & \\
\hline \multirow[t]{2}{*}{ YR4 } & -0.03 & -0.10 & 0.03 & -0.03 & -0.06 & -0.05 & 0.00 & -0.05 & -0.11 & -0.05 & 1.00 & & \\
\hline & 0.23 & 0.00 & 0.22 & 0.31 & 0.03 & 0.08 & 0.99 & 0.07 & 0.00 & 0.07 & & & \\
\hline \multirow[t]{2}{*}{ YR5 } & 0.13 & -0.01 & -0.11 & 0.03 & 0.13 & 0.01 & -0.09 & 0.17 & -0.42 & -0.20 & -0.06 & 1.00 & \\
\hline & 0.00 & 0.85 & 0.00 & 0.30 & 0.00 & 0.72 & 0.00 & 0.00 & 0.00 & 0.00 & 0.02 & & \\
\hline \multirow[t]{2}{*}{$22-24$} & 0.04 & -0.02 & 0.01 & 0.02 & -0.02 & -0.03 & -0.01 & -0.06 & -0.03 & -0.02 & 0.01 & 0.10 & 1.00 \\
\hline & 0.17 & 0.60 & 0.63 & 0.53 & 0.46 & 0.32 & 0.62 & 0.04 & 0.29 & 0.51 & 0.70 & 0.00 & \\
\hline
\end{tabular}


Table 5 Continued: Correlation coefficients

\begin{tabular}{|c|c|c|c|c|c|c|c|c|c|c|c|c|c|}
\hline & RES & $\mathrm{CTH}$ & CLESS & PAS & PRE & $\mathrm{OTH}$ & PREP & $\mathrm{F}$ & YR2 & YR3 & YR4 & YR5 & $22-24$ \\
\hline \multirow[t]{2}{*}{$25-27$} & 0.00 & -0.01 & 0.01 & -0.02 & 0.00 & -0.03 & 0.00 & 0.03 & -0.16 & 0.04 & 0.04 & 0.18 & -0.21 \\
\hline & 0.87 & 0.73 & 0.74 & 0.47 & 0.87 & 0.35 & 0.94 & 0.22 & 0.00 & 0.19 & 0.14 & 0.00 & 0.00 \\
\hline \multirow[t]{2}{*}{$28-30$} & 0.02 & 0.00 & 0.02 & 0.03 & 0.02 & 0.01 & 0.04 & -0.04 & -0.11 & -0.01 & 0.05 & 0.16 & -0.12 \\
\hline & 0.50 & 0.92 & 0.57 & 0.37 & 0.43 & 0.79 & 0.18 & 0.12 & 0.00 & 0.74 & 0.10 & 0.00 & 0.00 \\
\hline \multirow[t]{2}{*}{$>30$} & 0.04 & 0.03 & -0.03 & -0.03 & 0.06 & -0.01 & 0.02 & 0.04 & -0.09 & -0.01 & 0.04 & 0.16 & -0.08 \\
\hline & 0.14 & 0.24 & 0.30 & 0.24 & 0.04 & 0.65 & 0.58 & 0.12 & 0.00 & 0.75 & 0.18 & 0.00 & 0.01 \\
\hline \multirow[t]{2}{*}{$76-100$} & 0.03 & 0.03 & 0.00 & -0.02 & -0.02 & -0.02 & 0.04 & 0.03 & 0.03 & 0.00 & -0.03 & -0.03 & 0.00 \\
\hline & 0.33 & 0.23 & 0.93 & 0.58 & 0.50 & 0.59 & 0.19 & 0.29 & 0.29 & 1.00 & 0.29 & 0.26 & 0.94 \\
\hline \multirow[t]{2}{*}{$101-150$} & 0.01 & 0.02 & 0.02 & 0.01 & 0.04 & 0.03 & -0.03 & 0.04 & 0.01 & -0.02 & -0.01 & 0.08 & 0.04 \\
\hline & 0.77 & 0.50 & 0.46 & 0.76 & 0.12 & 0.22 & 0.35 & 0.19 & 0.80 & 0.39 & 0.67 & 0.01 & 0.18 \\
\hline \multirow[t]{2}{*}{$151-175$} & -0.01 & 0.03 & -0.02 & 0.01 & 0.01 & 0.01 & -0.03 & 0.06 & -0.06 & 0.07 & 0.03 & 0.08 & 0.04 \\
\hline & 0.87 & 0.27 & 0.52 & 0.74 & 0.72 & 0.75 & 0.24 & 0.04 & 0.02 & 0.01 & 0.23 & 0.00 & 0.14 \\
\hline \multirow[t]{2}{*}{$176<$} & 0.06 & -0.03 & -0.03 & 0.04 & 0.08 & 0.10 & -0.07 & 0.07 & 0.02 & 0.01 & -0.05 & 0.21 & -0.11 \\
\hline & 0.05 & 0.30 & 0.22 & 0.19 & 0.00 & 0.00 & 0.02 & 0.01 & 0.52 & 0.81 & 0.07 & 0.00 & 0.00 \\
\hline \multirow[t]{2}{*}{ ENG } & -0.03 & 0.05 & 0.02 & -0.01 & 0.05 & -0.02 & -0.02 & -0.35 & 0.66 & -0.25 & -0.08 & -0.31 & -0.05 \\
\hline & 0.23 & 0.10 & 0.59 & 0.69 & 0.09 & 0.48 & 0.49 & 0.00 & 0.00 & 0.00 & 0.00 & 0.00 & 0.08 \\
\hline \multirow[t]{2}{*}{ NUR } & 0.08 & 0.06 & -0.07 & -0.06 & 0.02 & 0.01 & -0.04 & 0.26 & -0.27 & 0.27 & 0.00 & 0.28 & 0.03 \\
\hline & 0.00 & 0.03 & 0.01 & 0.02 & 0.59 & 0.82 & 0.17 & 0.00 & 0.00 & 0.00 & 0.96 & 0.00 & 0.26 \\
\hline \multirow[t]{2}{*}{ LAW } & 0.09 & -0.02 & -0.11 & 0.06 & 0.14 & 0.02 & -0.05 & 0.08 & -0.34 & -0.16 & -0.02 & 0.78 & 0.08 \\
\hline & 0.00 & 0.52 & 0.00 & 0.05 & 0.00 & 0.48 & 0.07 & 0.00 & 0.00 & 0.00 & 0.57 & 0.00 & 0.01 \\
\hline \multirow[t]{2}{*}{$\mathrm{A} / \mathrm{S}$} & -0.07 & -0.03 & 0.06 & 0.03 & -0.12 & 0.02 & 0.05 & -0.04 & -0.41 & 0.00 & 0.09 & -0.17 & -0.01 \\
\hline & 0.01 & 0.28 & 0.03 & 0.24 & 0.00 & 0.52 & 0.06 & 0.15 & 0.00 & 0.89 & 0.00 & 0.00 & 0.66 \\
\hline \multirow[t]{2}{*}{ EDU } & -0.05 & -0.08 & 0.05 & 0.02 & -0.10 & -0.09 & 0.00 & 0.02 & -0.09 & -0.03 & -0.02 & -0.06 & 0.00 \\
\hline & 0.05 & 0.01 & 0.06 & 0.55 & 0.00 & 0.00 & 0.96 & 0.56 & 0.00 & 0.31 & 0.59 & 0.04 & 0.87 \\
\hline
\end{tabular}


Table 5 Continued: Correlation coefficients

\begin{tabular}{|c|c|c|c|c|c|c|c|c|c|c|c|c|}
\hline & $25-27$ & $28-30$ & $>30$ & $76-100$ & $101-150$ & $151-175$ & $176<$ & ENG & NUR & Law & $\mathrm{A} / \mathrm{S}$ & EDU \\
\hline $25-27$ & 1.00 & & & & & & & & & & & \\
\hline \multirow[t]{2}{*}{$28-30$} & -0.06 & 1.00 & & & & & & & & & & \\
\hline & 0.03 & & & & & & & & & & & \\
\hline \multirow[t]{2}{*}{$>30$} & -0.04 & -0.02 & 1.00 & & & & & & & & & \\
\hline & 0.16 & 0.44 & & & & & & & & & & \\
\hline \multirow[t]{2}{*}{ 76-100 } & -0.01 & 0.01 & 0.04 & 1.00 & & & & & & & & \\
\hline & 0.67 & 0.69 & 0.20 & & & & & & & & & \\
\hline \multirow[t]{2}{*}{$101-150$} & -0.05 & 0.04 & -0.01 & -0.14 & 1.00 & & & & & & & \\
\hline & 0.10 & 0.20 & 0.85 & 0.00 & & & & & & & & \\
\hline \multirow[t]{2}{*}{$151-175$} & 0.08 & 0.02 & -0.03 & -0.11 & -0.11 & 1.00 & & & & & & \\
\hline & 0.01 & 0.59 & 0.23 & 0.00 & 0.00 & & & & & & & \\
\hline \multirow[t]{2}{*}{$176<$} & -0.01 & -0.01 & 0.04 & -0.19 & -0.19 & -0.14 & 1.00 & & & & & \\
\hline & 0.84 & 0.81 & 0.18 & 0.00 & 0.00 & 0.00 & & & & & & \\
\hline \multirow[t]{2}{*}{ ENG } & -0.14 & -0.08 & -0.06 & -0.03 & -0.02 & -0.07 & 0.01 & 1.00 & & & & \\
\hline & 0.00 & 0.00 & 0.03 & 0.25 & 0.54 & 0.02 & 0.75 & & & & & \\
\hline \multirow[t]{2}{*}{ NUR } & 0.20 & 0.08 & 0.10 & 0.02 & 0.01 & 0.13 & 0.03 & -0.21 & 1.00 & & & \\
\hline & 0.00 & 0.01 & 0.00 & 0.54 & 0.61 & 0.00 & 0.22 & 0.00 & & & & \\
\hline \multirow[t]{2}{*}{ LAW } & 0.06 & 0.10 & 0.11 & -0.04 & 0.06 & 0.05 & 0.20 & -0.26 & -0.13 & 1.00 & & \\
\hline & 0.04 & 0.00 & 0.00 & 0.14 & 0.02 & 0.08 & 0.00 & 0.00 & 0.00 & & & \\
\hline \multirow[t]{2}{*}{$\mathrm{A} / \mathrm{S}$} & -0.01 & 0.03 & -0.03 & 0.00 & -0.03 & 0.01 & -0.14 & -0.32 & -0.16 & -0.20 & 1.00 & \\
\hline & 0.74 & 0.26 & 0.37 & 0.96 & 0.29 & 0.75 & 0.00 & 0.00 & 0.00 & 0.00 & & \\
\hline \multirow[t]{2}{*}{ EDU } & -0.02 & -0.02 & -0.01 & -0.04 & -0.05 & -0.03 & -0.04 & -0.08 & -0.04 & -0.05 & -0.06 & 1.00 \\
\hline & 0.56 & 0.44 & 0.61 & 0.11 & 0.11 & 0.23 & 0.11 & 0.01 & 0.17 & 0.09 & 0.04 & \\
\hline
\end{tabular}


Table 6: Variance Inflation Factor estimates

\begin{tabular}{lr} 
Variables & VIF \\
\hline FEM & 1.29 \\
YR2 & 3.84 \\
YR3 & 1.96 \\
YR4 & 1.1 \\
YR5 & 5.66 \\
AGE2 & 1.18 \\
AGE3 & 1.21 \\
AGE4 & 1.11 \\
AGE5 & 1.07 \\
INC2 & 1.14 \\
INC3 & 1.17 \\
INC4 & 1.14 \\
INC5 & 1.34 \\
ENG & 2.04 \\
NUR & 2.34 \\
LAW & 4.74 \\
A/S & 2.22 \\
EDUC & 1.13 \\
RESP & 1.08 \\
CGHT & 1.1 \\
CLESS & 1.09 \\
PASS & 1.11 \\
PRESS & 1.19 \\
OTHER & 1.11 \\
PREP & 1.06 \\
\hline & \\
\hline &
\end{tabular}

The results of the regression analysis of the mean score on the academic dishonesty situations are presented in Table 7. The dependent variable is respondents' mean scores on the academic dishonesty situation statements (ADSC) presented. The independent variables are as previously specified and include demographic and student attitude variables. The F-value $(\mathrm{p}<0.05)$ indicates that the model is significant at the $5 \%$ level of significance. The R-square for the regression is 17.85 indicating that about $18 \%$ of the variations in mean scores are explained by this model. 
Table 7: Regression coefficients for determinants of academic dishonesty knowledge

\begin{tabular}{|c|c|c|c|c|}
\hline Term & Coef. & SE Coef. & T-Value & P-Value \\
\hline RESP & 0.0426 & 0.0116 & 3.68 & 0.00 \\
\hline CGHT & 0.0899 & 0.0146 & 6.17 & 0.00 \\
\hline CLESS & -0.0713 & 0.0132 & -5.41 & 0.00 \\
\hline PASS & -0.039 & 0.0121 & -3.23 & 0.00 \\
\hline PRESS & 0.0102 & 0.0141 & 0.72 & 0.47 \\
\hline OTHER & -0.0012 & 0.0136 & -0.09 & 0.93 \\
\hline PREP & 0.0418 & 0.0169 & 2.48 & 0.01 \\
\hline FEM & 0.0693 & 0.0359 & 1.93 & 0.05 \\
\hline YR2 & 0.3103 & 0.0607 & 5.11 & 0.00 \\
\hline YR3 & 0.2852 & 0.0626 & 4.56 & 0.00 \\
\hline YR4 & 0.17 & 0.13 & 1.31 & 0.19 \\
\hline YR5 & 0.2186 & 0.0918 & 2.38 & 0.02 \\
\hline AGE2 & -0.041 & 0.0364 & -1.13 & 0.26 \\
\hline AGE3 & -0.0108 & 0.0569 & -0.19 & 0.85 \\
\hline AGE4 & -0.1147 & 0.0913 & -1.26 & 0.21 \\
\hline AGE5 & 0.202 & 0.136 & 1.49 & 0.14 \\
\hline INC2 & -0.0423 & 0.0496 & -0.85 & 0.39 \\
\hline INC3 & 0.0473 & 0.0497 & 0.95 & 0.34 \\
\hline INC4 & -0.074 & 0.0623 & -1.19 & 0.24 \\
\hline INC5 & 0.0242 & 0.0438 & 0.55 & 0.58 \\
\hline ENG & 0.0528 & 0.0479 & 1.1 & 0.27 \\
\hline NUR & -0.0675 & 0.0809 & -0.83 & 0.40 \\
\hline LAW & 0.259 & 0.0968 & 2.68 & 0.01 \\
\hline $\mathrm{A} / \mathrm{S}$ & 0.1093 & 0.0576 & 1.9 & 0.06 \\
\hline EDU & -0.157 & 0.139 & -1.13 & 0.26 \\
\hline F-value & 11.13 & & & 0.00 \\
\hline R-Square & 17.85 & & & \\
\hline
\end{tabular}

*** Significant at the 1 percent level, ** Significant at the 5 percent level, * Significant at the 10 percent level. 
Table 8: Regression results for individual academic dishonesty situation questions

\begin{tabular}{|c|c|c|c|c|c|c|c|c|c|}
\hline Variables & V1 & $\mathrm{V} 2$ & V3 & V4 & V5 & V6 & V7 & V8 & V9 \\
\hline RESPECT & $-0.088 * * *$ & -0.008 & -0.035 & $0.045^{*}$ & $0.080 * * *$ & $0.043^{*}$ & $0.045^{*}$ & 0.026 & $0.080 * * *$ \\
\hline CAUGHT & -0.062 & $0.055^{* *}$ & $-0.068^{*}$ & $0.140^{* * *}$ & $0.073 * *$ & 0.027 & $0.121^{* * *}$ & $0.131 * * *$ & $0.102 * * *$ \\
\hline CARELESS & $-0.091 * * *$ & $-0.094 * * *$ & 0.023 & $-0.049 *$ & $-0.080 * * *$ & $-0.111 * * *$ & $-0.072 * * *$ & $-0.085^{* * *}$ & $-0.097 * * *$ \\
\hline PASSING & $0.070 * *$ & -0.015 & -0.048 & $-0.087 * * *$ & $-0.065 * *$ & $-0.077 * * *$ & -0.020 & $-0.056^{*}$ & $-0.056^{*}$ \\
\hline PRESSURE & -0.012 & 0.017 & 0.039 & 0.002 & 0.024 & 0.049 & 0.013 & 0.003 & $0.071 * *$ \\
\hline OTHERS & -0.036 & 0.008 & 0.023 & -0.014 & -0.023 & 0.038 & 0.013 & -0.042 & $-0.119 * * *$ \\
\hline PREPARED & $-0.155 * * *$ & -0.036 & -0.023 & $0.106^{* * *}$ & $0.085^{* *}$ & $0.081 * *$ & 0.010 & 0.025 & 0.025 \\
\hline FEM & 0.069 & 0.043 & -0.013 & 0.037 & 0.065 & $0.128^{*}$ & $0.140 *$ & 0.092 & -0.080 \\
\hline YR2 & 0.258 & $0.364 * * *$ & $0.355^{* *}$ & $0.425^{* * *}$ & $0.449 * * *$ & $0.276^{* *}$ & $0.563 * * *$ & -0.010 & $0.785^{* * *}$ \\
\hline YR3 & 0.115 & $0.224 * *$ & 0.189 & $0.379 * * *$ & $0.600 * * *$ & $0.312^{* *}$ & $0.662 * * *$ & $-0.353 * *$ & $0.683^{* * *} *$ \\
\hline YR4 & 0.039 & 0.066 & 0.074 & -0.330 & -0.144 & $-0.564 * *$ & 0.268 & $0.630 * *$ & $0.968 * * *$ \\
\hline YR5 & -0.011 & -0.239 & $0.424 *$ & 0.205 & $0.568 * * *$ & 0.273 & $0.688 * * *$ & -0.300 & $0.970 * * *$ \\
\hline $22-24$ & -0.102 & 0.010 & -0.022 & -0.090 & -0.132 & 0.021 & -0.049 & -0.126 & -0.036 \\
\hline $25-27$ & $-0.441 * * *$ & -0.122 & -0.031 & 0.050 & -0.091 & 0.015 & -0.057 & 0.051 & -0.013 \\
\hline $28-30$ & $-0.428^{*}$ & -0.113 & -0.191 & 0.116 & -0.196 & 0.007 & $-0.371 * *$ & -0.214 & 0.208 \\
\hline$>30$ & $-0.872 * *$ & -0.072 & -0.278 & 0.207 & 0.413 & 0.344 & 0.324 & 0.284 & 0.207 \\
\hline $76-100$ & 0.192 & -0.041 & 0.170 & 0.032 & $-0.196^{*}$ & -0.090 & 0.046 & -0.127 & -0.046 \\
\hline $101-150$ & -0.077 & 0.086 & -0.002 & -0.046 & 0.061 & 0.145 & 0.095 & 0.059 & -0.131 \\
\hline $151-175$ & $0.633^{* * *}$ & -0.059 & 0.074 & 0.110 & -0.106 & 0.041 & -0.061 & $-0.390 * *$ & -0.153 \\
\hline $176<$ & 0.012 & 0.016 & 0.014 & 0.008 & -0.058 & 0.100 & 0.084 & 0.101 & 0.033 \\
\hline ENG & $-0.399 * * *$ & 0.087 & 0.105 & 0.159 & 0.015 & 0.050 & 0.095 & 0.005 & 0.114 \\
\hline NUR & -0.172 & $0.268 * *$ & 0.084 & -0.268 & -0.209 & -0.027 & -0.227 & 0.149 & -0.287 \\
\hline LAW & 0.053 & $0.599 * * *$ & 0.131 & $0.393^{*}$ & 0.275 & 0.138 & -0.015 & 0.309 & 0.093 \\
\hline $\mathrm{A} / \mathrm{S}$ & -0.224 & 0.144 & -0.082 & $0.420 * * *$ & $0.238^{*}$ & 0.070 & 0.040 & 0.112 & 0.022 \\
\hline EDUC & 0.516 & -0.067 & -0.405 & 0.201 & 0.107 & -0.220 & -0.517 & -0.044 & 0.041 \\
\hline $\mathrm{R}$-square & $6.92 \%$ & $7.16 \%$ & $3.44 \%$ & $7.06 \%$ & $7.70 \%$ & $7.29 \%$ & $11.01 \%$ & $4.80 \%$ & $12.56 \%$ \\
\hline $\mathrm{F}$ & 3.82 & 3.96 & 3.81 & 3.82 & 4.28 & 4.04 & 6.35 & 2.59 & 7.37 \\
\hline
\end{tabular}

*** Significant at the 1 percent level, ** Significant at the 5 percent level, * Significant at the 10 percent level. 
Table 8 Continued: Regression results for individual academic dishonesty situation questions

\begin{tabular}{|c|c|c|c|c|c|c|c|c|c|}
\hline Variables & V10 & V11 & V12 & V13 & V14 & V15 & V16 & V17 & V18 \\
\hline RESPECT & $0.097 * * *$ & $0.044 *$ & 0.015 & 0.036 & 0.049 & 0.047 & $0.139 * * *$ & $0.051 * *$ & $0.088 * * *$ \\
\hline CAUGHT & $0.082 * *$ & $0.140 * * *$ & $0.170 * * *$ & $0.165^{* * *}$ & 0.039 & $0.150 * * *$ & $0.143 * * *$ & $0.124 * * *$ & $0.096 * * *$ \\
\hline CARELESS & -0.043 & $-0.121 * * *$ & $-0.074 * * *$ & $-0.111 * * *$ & 0.026 & -0.019 & $-0.083 * * *$ & $-0.106^{* * *}$ & $-0.090 * * *$ \\
\hline PASSING & $-0.051 *$ & $-0.046^{*}$ & -0.021 & $-0.088 * * *$ & 0.025 & $-0.050 *$ & $-0.092 * * *$ & -0.008 & -0.006 \\
\hline PRESSURE & -0.026 & 0.003 & $0.046^{*}$ & $0.070 * *$ & -0.038 & $-0.066^{* *}$ & -0.049 & 0.027 & 0.003 \\
\hline OTHERS & $-0.069 * *$ & -0.028 & $0.045^{*}$ & 0.026 & -0.050 & $0.065 * *$ & 0.018 & $0.055^{* *}$ & $0.048 * *$ \\
\hline PREPARED & 0.037 & $0.079 * *$ & 0.039 & $0.097 * *$ & $0.094 * *$ & 0.043 & $0.135^{* * *}$ & $0.107 * * *$ & $0.070 * *$ \\
\hline FEM & 0.127 & 0.080 & 0.066 & $0.162 *$ & -0.121 & $0.209^{* *}$ & 0.007 & $0.115^{*}$ & $0.147 * *$ \\
\hline YR2 & 0.198 & $0.487 * * *$ & $0.585^{* * *}$ & 0.191 & $-0.440 * * *$ & $0.333^{* *}$ & -0.125 & $0.413 * * *$ & $0.316^{* * *}$ \\
\hline YR3 & 0.204 & $0.551 * * *$ & $0.541 * * *$ & 0.122 & $-0.340 * *$ & $0.291 * *$ & 0.080 & $0.569 * * *$ & $0.452 * * *$ \\
\hline YR4 & $0.729 * *$ & 0.031 & 0.245 & 0.204 & -0.321 & $0.556^{*}$ & 0.155 & $0.492 * *$ & 0.197 \\
\hline YR5 & 0.076 & $0.596 * * *$ & $0.362 * *$ & 0.214 & $-0.603 * *$ & 0.218 & -0.045 & $0.414^{* *}$ & 0.265 \\
\hline $22-24$ & $-0.185 * *$ & -0.048 & -0.031 & -0.002 & 0.077 & 0.027 & -0.003 & -0.099 & -0.010 \\
\hline $25-27$ & -0.138 & -0.027 & 0.063 & 0.109 & 0.194 & 0.168 & 0.010 & -0.025 & 0.008 \\
\hline $28-30$ & $-0.548 * * *$ & -0.090 & -0.050 & $-0.528 * *$ & 0.339 & 0.104 & -0.145 & -0.048 & 0.022 \\
\hline$>30$ & $0.740 * *$ & 0.202 & 0.296 & 0.111 & 0.423 & 0.311 & 0.357 & 0.265 & 0.309 \\
\hline $76-100$ & -0.142 & -0.040 & 0.006 & -0.064 & -0.148 & -0.181 & -0.138 & -0.030 & 0.080 \\
\hline $101-150$ & 0.106 & 0.069 & $0.193 * *$ & 0.062 & -0.063 & $0.194 *$ & 0.169 & 0.000 & -0.020 \\
\hline $151-175$ & -0.091 & -0.136 & -0.108 & 0.003 & $-0.354 * *$ & $-0.269 *$ & $-0.233^{*}$ & -0.067 & -0.125 \\
\hline $176<$ & 0.078 & 0.053 & $0.144^{*}$ & 0.018 & -0.124 & -0.050 & 0.080 & 0.036 & -0.039 \\
\hline ENG & $-0.214 *$ & $0.219 * *$ & 0.027 & 0.025 & $0.268 * *$ & -0.013 & 0.115 & $0.171 * *$ & $0.239 * * *$ \\
\hline NUR & -0.060 & -0.253 & -0.165 & $-0.383 * *$ & $0.397 *$ & -0.012 & 0.081 & -0.160 & -0.113 \\
\hline LAW & $0.414^{*}$ & 0.181 & 0.207 & -0.124 & $0.589 * *$ & 0.300 & $0.531 * *$ & 0.148 & $0.295^{*}$ \\
\hline $\mathrm{A} / \mathrm{S}$ & 0.021 & 0.123 & 0.108 & -0.040 & $0.378 * *$ & $0.258^{*}$ & 0.144 & 0.088 & 0.091 \\
\hline EDUC & -0.259 & $-0.468^{*}$ & $-0.679 * * *$ & -0.129 & 0.252 & 0.344 & $-0.661 * *$ & $-0.708 * * *$ & -0.169 \\
\hline $\mathrm{R}$-square & $7.57 \%$ & $12.55 \%$ & $15.29 \%$ & $7.59 \%$ & $5.33 \%$ & $5.49 \%$ & $10.71 \%$ & $14.11 \%$ & $10.72 \%$ \\
\hline $\mathrm{F}$ & 4.21 & 7.36 & 9.25 & 4.2 & 2.89 & 2.97 & 6.16 & 8.43 & 6.160 \\
\hline
\end{tabular}

*** Significant at the 1 percent level, ** Significant at the 5 percent level, * Significant at the 10 percent level.

Student gender was found to be a statistically significant determinant of the mean score on the academic dishonesty situation statements. Female students scored significantly $(p=0.05)$ higher on the situation questions than male students indicating better awareness about academic dishonesty. Age was not found to be a significant determinant of students' scores on the academic dishonesty situation questions. Compared to students less than 21 years old, none of the results for age was significant at any of the accepted level of significance. Similar to age, family income level was not found to be a determinant of students' mean scores on the situation questions. Compared to monthly family income level of N75,000, none of the income classification was found to have a statistically significant different score at any of the usual levels of significance.

The students' years of studies was found to be a statistically significant determinant of variations in mean scores on the academic dishonesty situation questions. All the other years were compared to first year. Year $2(\mathrm{p}<0.01)$, year $3(\mathrm{p}<0.01)$, and year $5(\mathrm{p}<0.05)$ students scored significantly higher on the situation questions than year one students indicating that higher level students are more aware of academic dishonesty situations. Even though year 4 students scored higher than year 1 students, the result was not statistically significant.

The area of study of the students were compared to business students. The result showed that only law students and arts and sciences students scored significantly higher than business students $(\mathrm{p}<0.01$, and $\mathrm{p}<0.10$ respectively). 
Engineering, nursing, and education students did not have statistically significantly different scores from those of business students even though nursing and education students had lower scores than business students.

Students attitude questions reflect how the student feels about academic dishonesty on them, and their readiness for exams. The signs on the estimates were generally as expected. Students who believe that they could lose respect if they are known to receive help, believe that there is a good chance that they would be caught, and students who indicated that they were well-prepared for exams, scored significantly higher on the mean situation statements $(\mathrm{p}<0.01, \mathrm{p}<0.01, \mathrm{p}<0.05$ respectively). These two results are consistent with theory of self-concept maintenance postulations of Mazar, Amir and Ariely, (2008) that the decision to cheat involves a balance between expected gain from cheating, and the need to preserve one's self-concept of honesty. On the other hand, students who would not care whether they were caught or not as long as they passed the course, and students who indicated that passing was the most important thing to them had statistically significant negative signs on the mean situation scores $(\mathrm{p}<0.01, \mathrm{p}<0.01$ respectively).

This is consistent with earlier findings about the role of external pressure on the decision to be involved in academic dishonesty (Henning, et al. 2014). The study by Henning, et al. (2014) found that students' actions (honest or dishonest) were guided by family and friends, the need to do well, issues of morality and institutional guidelines. There was no statistically significant difference in the mean scores of students who believed that other students will cheat if they could.

\section{Conclusion}

This paper explored the effects of attitude and students' perceptions of academic dishonesty in Nigeria. Many factors were shown to affect how students perceive academic dishonesty and their understanding of academic dishonesty situations. The results indicate that both students' personal beliefs and societal pressure to succeed and advance in a competitive educational environment, impact students' perceptions about academic dishonesty. Students who place less weight on the cost of being caught were less likely to perceive academic dishonesty situations as such. Overall, the students had a good understanding of academic dishonesty situations as shown in the generally high academic dishonesty questions means.

The governments have instituted numerous measures to stem the rise of academic dishonesty in Nigeria. These measures range from educating the students about what academic dishonesty was to making academic dishonesty a criminal offense. One implication of these results is that the emphasis of public education on academic dishonesty should be changed from awareness to effect. Academic dishonesty education should stress the impact of dishonesty on the individual and society. For instance, it could stress the impact on the students' self-perception and the effect on the value of the diplomas earned by the students.

\section{References}

Adebayo, S. O. (2011). Common Cheating Behaviour Among Nigerian University Students: A Case Study of University of Ado-Ekiti, Nigeria.World Journal of Education, 1(1), 144-149.

Akakandelwa, A., \& Jain, P., \& Wamundila, S. (2013). Academic dishonesty: A comparative study of students of library and information science in Botswana and Zambia. Journal of Information Ethics, 22(2), 137-150.

Alutu, A.N., and Aluede, O. (2005). The role of counselling in dealing with examination malpractice and examination ethics. Revista Espanola de Orientacion y Psicopedagogia, 16, 189-198.

Alutu, A. N., and Aluede, O. (2006). Secondary schools student's perception of examination malpractices and examination ethics.Journal of Human Ecology, 20(4), 295-300.

Balbuena, Sherwin E., and Lamela Renee A., (2015). Prevalence, motives and views of academic dishonesty in higher education. Asia Pacific Journal of Multidisciplinary Research, 3(2), 69-75.

Cazan, A.M \& Iacob, C. (2017). Academic dishonesty, personality traits and academic adjustment. Bulletin of the Transilvania University of Braşov, 10(59)(2), 59-66.

Eriksson, L and McGee, T. R. (2015). Academic dishonesty amongst Australian criminal

justice and policing university students: Individual and contextual factors. International Journal for Educational Integrity. DOI 10.1007/s40979-015-0005-3

Huang, C., Yang, S. C. and Chen, A. (2015). The relationships among students' achievement

goals, willingness to report academic dishonesty, and engaging in academic dishonesty. Social Behavior and Personality,43(1), 27-38.

Jones, D. L. R. (2011). Academic dishonesty: Are more students cheating? Norfolk State 
University Business Communication Quarterly, 74(2), 141-150.

Mazar, N., Amir, O., \& Ariely, D. (2008). The dishonesty of honest people: A theory of self-concept maintenance. Journal of Marketing Research, XLV, (December 2008), 633-644

McCabe, D. L. (2009). Academic Dishonesty in nursing schools: An empirical investigation.Journal of Nursing Education, 48(11), 614-624.

Mohr, T., Ingram, D., Fell, N., \& Mobey, R. (2011). The case for academic integrity in physical therapist education. Journal of Physical Therapy Education, 25(2), 51-56

Olatunbosun, J. B. (2009). Examination malpractice in secondary schools in Nigeria: What sustains it?European Journal of Educational Studies, 1(3), 101-108.

Orim S. M. (2016). Perspectives of Academic Integrity from Nigeria. In: Bretag T. (eds) Handbook of Academic Integrity. Springer, Singapore

Penn State University. (2018). Retrieved from https://onlinecourses.science.psu.edu/stat501/node/347 on March 25, 2018.

Rabi, S. M., Patton, L. R., Fjortoft, N., and Zgarrick, D. P. (2006). Characteristics, prevalence, attitudes, and perceptions of academic dishonesty among pharmacy students. American Journal of Pharmaceutical Education. 70(4), 1-8,

Resureccion, P. F. (2012). The impact of faculty, peers and integrity culture in the academe on academic misconduct among Filipino students: An empirical study based on social cognitive theory. International Journal of Academic Research in Business and Social Sciences, 2(12), 33-50.

Rinn, A. N., Boazman, J., Jackson, A. and Barrio, B. (2014). Locus of control, academic self-

concept, and academic dishonesty among high ability college students. Journal of the Scholarship of Teaching and Learning, 14(4), 88-114.

Sulphey, M.M. \& Jnaneswer, K. (2013). The Journal of Contemporary Management Research, ～Vol. 18， Issue No. 2, 2013 pp. 57-72.

Tefera T. and Kinde G. (2009). Faculties' Perception and Responses to Academic Dishonesty of Undergraduate Students in Education, Business and Economics. Ethiopian Journal of Education and Science, 4(2), 57-72.

Ubaka C, Gbenga F, Sunday N, Ndidiamaka E., (2013). Academic dishonesty among Nigerian pharmacy students: a comparison with United Kingdom. African Journal of Pharmacology, 7(1). 1934-41.

Whitley, B. E. (1998). Factors associated with cheating among college students: A review. Research in Higher Education, 39, 235-274.

Appendix 1 Study Questionnaire.

Appendix 1 Continued: Study Questionnaire.

\begin{tabular}{|c|c|c|c|c|c|c|}
\hline \multicolumn{7}{|c|}{ For each of the following questions, state whether you agree or not. } \\
\hline & & 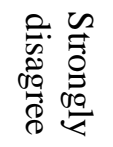 & 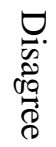 & 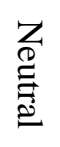 & 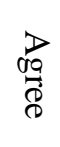 & 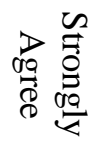 \\
\hline 1 & People would lose respect for me is they found out that I had help. & & & & & \\
\hline 2 & There is a good chance that I would get caught if I looked at another student's exam. & & & & & \\
\hline 3 & I would not care whether I am caught or nor as long as I pass the exam. & & & & & \\
\hline 4 & Passing is the most important thing to me. & & & & & \\
\hline 5 & There is too much pressure on students to pass a course. & & & & & \\
\hline 6 & Other students will cheat on exams if they could. & & & & & \\
\hline 7 & I consider myself well prepared for exams. & & & & & \\
\hline
\end{tabular}

\section{Appendix 1 Continued: Study Questionnaire}


This questionnaire will only be used for research purposes. Please provide the following information as honestly as possible. Do not write your name anywhere on this questionnaire. You cannot be identified in any way so your answers cannot be traced to you.

\begin{tabular}{|c|c|c|c|}
\hline & & & \\
\hline \multirow{2}{*}{1} & \multirow{2}{*}{ What is your gender? } & $\bigcirc$ & Female \\
\hline & & $\bigcirc$ & Male \\
\hline \multirow{5}{*}{2} & \multirow{5}{*}{ What is your current class? } & $\bigcirc$ & 1st Year \\
\hline & & $\bigcirc$ & 2nd Year \\
\hline & & $\bigcirc$ & 3rd Year \\
\hline & & $\bigcirc$ & 4th Year \\
\hline & & $\bigcirc$ & 5th Year \\
\hline \multirow{5}{*}{3} & \multirow{5}{*}{ What is your age range? } & $\bigcirc$ & 21 years or less \\
\hline & & $\bigcirc$ & $22-24$ years \\
\hline & & $\bigcirc$ & $25-27$ years \\
\hline & & $\bigcirc$ & 28-30 years \\
\hline & & $\bigcirc$ & Over years \\
\hline \multirow{5}{*}{4} & \multirow{5}{*}{ What is your family's monthly income level? } & $\bigcirc$ & $\mathrm{N} 75,000$ or less \\
\hline & & $\bigcirc$ & $\mathrm{N} 75,001$ to 100,000 \\
\hline & & $\bigcirc$ & $\mathrm{N} 101,000$ to 150,000 \\
\hline & & $\bigcirc$ & $\mathrm{N} 151,000$ to 175,000 \\
\hline & & $\bigcirc$ & More than 175,000 \\
\hline
\end{tabular}

